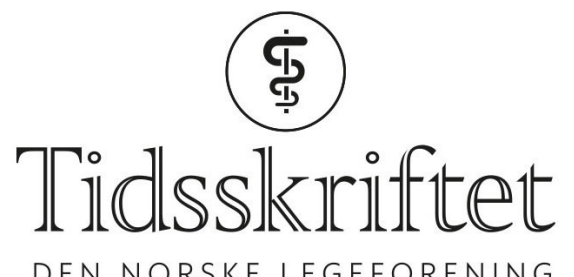

DEN NORSKE LEGEFORENING

\title{
Klovnen, livet og døden
}

MEDISIN OG KUNST

\section{ELISABETH HELLAND LARSEN}

E-post: mail@boascenekunst.no

Elisabeth Helland Larsen er barnebokforfatter og ansatt hos Sykehusklovnene. Hun tar nå en mastergrad i barne- og ungdomslitterær skrivekunst og formidling ved Norsk Barnebokinstitutt ved siden av å jobbe $20 \%$ i Sykehusklovnenes palliasjonsprosjekt.

Forfatter har fylt ut ICMJE-skjemaet og oppgir ingen interessekonflikter.

Klovnen har til alle tider vært en slags joker i samfunnet, som kortet i stokken fri for nummering og familiær tilhørighet. Jokeren er kortet som skiller seg ut, en fargesprakende figur som danser med et musikkinstrument $\mathrm{i}$ armene, en karakter som kan bevege seg fritt $\mathrm{i}$ samfunnet og krysse ulike tidsaldres strenge hierarkier.

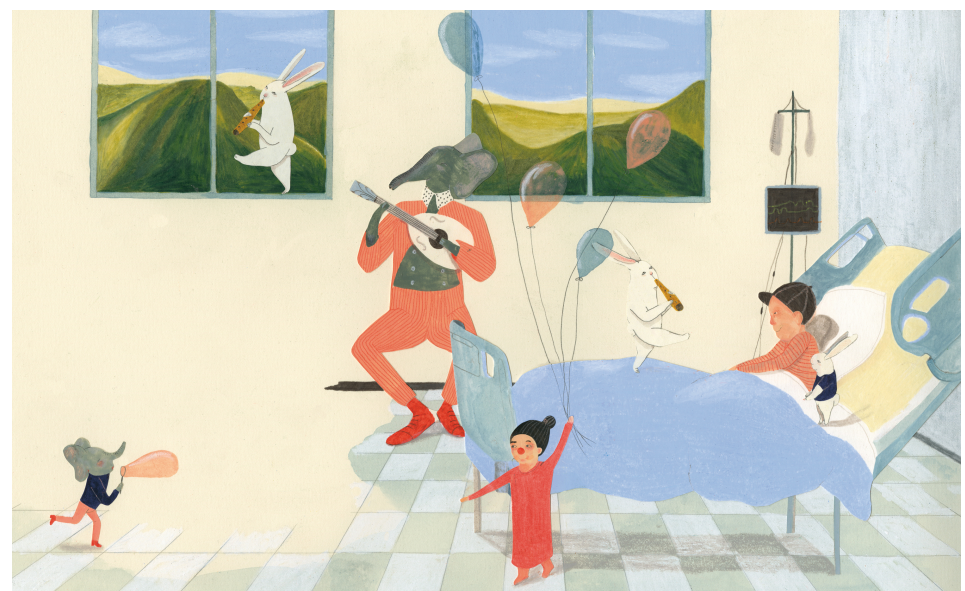

Fra boken Jeg er Klovnen. Illustrasjon: Marine Schneider/Magikon Forlag

Klovnens rolle har vært å forstørre, latterliggjøre, sette ting i perspektiv, stimulere det lekne og fantasifulle, frembringe latter og tårer, sette søkelyset på det tabubelagte, bygge broer av feiltrinn, anerkjenne det som er annerledes og bidra med musikk og poesi i alle livets faser.

Uansett hvor krevende utfordringer mennesket har vært utsatt for, har jokeren, klovnen, narren eller gjøgleren fått lov til å nære samfunnet med humor, fantasi og musikk. Kunst og kultur kan anses som limet i de fleste samfunn, og klovnens rolle har ofte fått en mytisk betydning i ritualer knyttet til menneskets liv og død. Klovnen kan sees som et symbol for mennesket, en som balanserer på linen mellom livet og døden og livnærer seg av kunsten å falle eller gjøre feil.

En av klovnens fremste kvaliteter er å være i nuet og stimulere de friske kreftene i medmennesker. Klovnen har en egen evne til å rette seg mot mennesket og krysse grenser med tillit, kjærlighet og lekens kraft. Vi kan kalle det klovnumikasjon. Også i livets tøffeste situasjoner kan små pustepauser med fokus på det som fortsatt virker skape magiske 
øyeblikk og gylne minner.

Spesielt i møte med barn og unge med alvorlige sykdommer eller tilstander kan det være vanskelig for pårørende å finne de ekstra kreftene til å stimulere barnets lek. Pårørende har ofte nok med å holde barnet, seg selv og familien oppe i en særdeles krevende situasjon og emosjonell reise. I møte med alvorlig sykdom eller død, kan klovner og andre kunstutrykk være med å representere, nære og speile barnets perspektiv.

Barn er barn og ungdom er ungdom, også i møte med sykdom, diagnoser eller død. Vår identitet og værekraft som mennesker skal styrkes, ikke gå i ett med en diagnose eller tilstand. Slik kan lek, humor, fantasi, musikk og poesi bli verktøy for å stimulere barnets kraftsenter og hente frem barnets egne ressurser, uavhengig av situasjonen det befinner seg i. Klovnen innehar muligheten til å kommunisere på en alternativ og nonverbal måte når det trengs.

Kunst og kultur kan anses som limet i de fleste samfunn, og klovnens rolle har ofte fått en mytisk betydning i ritualer knyttet til menneskets liv og død

Ordet poesi kan brukes om noe som vekker følelser og stemningsfullhet. I møte med terminalfasen - døden - kan den poetiske klovnen med ydmykhet og respekt være med å hente frem barnets eller ungdommens identitet og værekraft helt til det siste. Disse øyeblikkene, når barnet får lov til å være barn også i møte med døden, kan oppleves sterkt og befriende for alle berørte, både helsepersonell og pårørende. Uansett hvor langt et liv varer, skal vi gjøre vårt ytterste for å fylle det med et mangfold av innhold og livskvalitet.

I mange kulturer bruker man fortsatt narren, klovnen, dukkespillere eller musikere i seremonier knyttet til liv og død. Både ved inngang og utgang av livet benytter vi oss av kunst, kanskje fordi den kan romme så mye mer enn ord og handlinger, noe som ikke er så lett å beskrive, men som likevel fyller oss med en sansestimulerende opplevelse. Det vil si, noe som får oss til å gnistre litt ekstra, kjenne at vi lever og ikke er alene, akkurat her og nå.

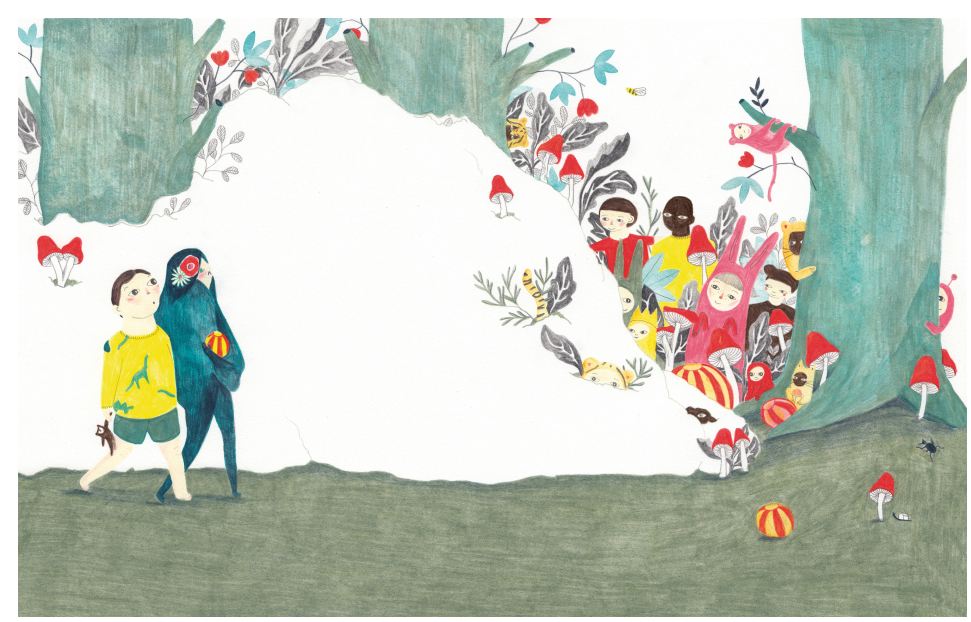

Fra boken Jeg er Døden. Illustrasjon: Marine Schneider/Magikon Forlag

Mennesket har til enhver tid hentet styrke fra flokken rundt seg i krevende situasjoner. Noen kan bidra med medisiner, noen med praktisk tilrettelegging, noen med kjærlighet og oppmerksomhet og andre igjen med latter, poesi og lek.

Døden oppfattes ofte som tabu i vår nordiske kultur, sammenlignet med mange andre land. I andre kulturer blir derimot barn og unge ofte inkludert i seremonier knyttet til liv og død, som i Mexico, hvor de døde feires en dag i året med farger og musikk. Kanskje er dette en måte å ufarliggjøre og tilnærme seg døden på, slik at den også kan bli en mer naturlig del av livet.

At barn og unge blir alvorlige syke og noen ganger går bort, skaker hele vår livsoppfatning. Det setter hele vårt livsløp opp ned og kan hverken forstås eller godtas. Desto viktigere blir det derfor, i slike ekstremt traumatiserende situasjoner, å ta vare på det friske i barnet eller ungdommen. Slik kan man få være seg selv og bli sett utover ens sykdom og diagnose. 
Kunsten kan bygge broer mellom fantasi og virkelighet, selv i håpløse situasjoner kan den skape håp og glede

Barnepalliasjon er et slikt begrep, og dreier seg om å dekke det helhetlige behovet til barn, unge og pårørende som står i krevende utfordringer ved livstruende eller livsbegrensende tilstander. Palliasjon betyr kappe eller lindring og handler om å øke deres livskvalitet i prosesser som kan vare i alt fra en kort periode til mange år.

Klovnen, kunst og kultur kan i dette øyemed også være en del av det helhetlige tilbudet til mennesker i unntakstilstand. I livets mest krevende prosesser har vi kanskje også behov for noen som kan binde sammen det mytologiske, spirituelle, åndelige og fysiske. Noen som kan krysse kategoriene og diagnosene og leke i døråpningen mellom virkeligheter. Kunsten kan bygge broer mellom fantasi og virkelighet, selv i håpløse situasjoner kan den skape håp og glede. Kanskje er det derfor klovner får lov til å bidra med sine verktøy på sykehus, eldrehjem, flyktningeleirer, gater og teatre slik at alle kan le og glemme for en liten stund. Kanskje kan slike gylne øyeblikk styrke oss til å gå gjennom det vanskelige og dyrke kjærligheten mellom oss, slik at vi kan bære det umulige sammen. Og kanskje kan klovnens filosofi og klovnumikasjon være med å inspirere andre yrkesgrupper som også møter små og store mennesker hver eneste dag.

Publisert: 19. mars 2021. Tidsskr Nor Legeforen. DOI: 10.4045/tidsskr.20.1012

(C) Tidsskrift for Den norske legeforening 2020. Lastet ned fra tidsskriftet.no 